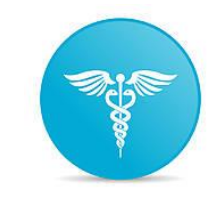

International Journal of Advances in Pharmacy and Biotechnology

Vol.1, Issue-1, 2015, 28-32

I J A P B

Research Article

Open Access

\title{
SCREENING AND ISOLATION OF L-GLUTAMINASE PRODUCING MARINE BACTERIAL CULTURES
}

\author{
S. Suneetha ${ }^{1}{ }^{*}$, M. Lakshminarasu ${ }^{1}$, T. Prabhakar ${ }^{2}$ and P. Venkat Rao ${ }^{2}$ \\ *1. Department of Biotechnology, IST, Jawaharlal Nehru Technological University, Hyderabad-08, \\ T.S., India. \\ 2. Pharmaceutical Biotechnology Division, A.U.College of Pharmaceutical Sciences, \\ Andhra University, Visakhapatnam-530003, A.P., India. \\ *Corresponding author e-mail: $\underline{\text { sujji_suni@yahoo.co.in }}$
}

Received: 02 May 2015

Revised: 06 May 2015

Accepted: 11 May 2015

\begin{abstract}
:
Microbial glutaminases have found applications in several fields. L-Glutaminase has received significant attention recently owing to its potential applications in medicine as an anticancer agent and flavor enhancing agent in food industries. Screening of extra cellular L-glutaminase producing marine bacterial strains isolated from sediment and water samples collected at different places along the beach of Bay of Bengal in Visakhapatnam were done by dye based procedure. Among the fifteen isolates LG24 gave highest activity of $18.82 \mathrm{U} / \mathrm{ml}$ with in $48 \mathrm{~h}$ where L-glutamine supplemented as sole carbon and nitrogen source in the media.
\end{abstract}

Key words: L-glutaminase, enzyme, extra cellular, marine, submerged fermentation, anticancer agent.

\section{INTRODUCTION:}

Microbial glutaminases have found applications in several fields. They had been tried as therapeutic agents in the treatment of cancer ${ }^{[1,2]}$ and HIV[3], as an analytical agent in determination of glutamine and glutamate ${ }^{4-6]}$, and in the production of specialty chemicals like threonine by gamma glutamyl transfer reactions ${ }^{[7]}$. L-glutaminase is the enzyme deaminating L-glutamine. The action of glutaminase plays a major role in the nitrogen metabolism of both prokaryotes and eukaryotes. In recent years glutaminase has attracted much attention with respect to proposed applications in pharmaceuticals as anti-leukemic agent ${ }^{[8]}$ and in food industry as flavor enhancing agent ${ }^{[9]}$. L-glutaminase in combination with or as an alternative to asparaginase could be of significance in enzyme therapy for cancer especially acute lymphocytic leukemia[8]. Its commercial importance as anticancer and flavor enhancing agent demands not only the search for better yielding viable strains, but also economically viable bioprocesses for its large scale production[10]. Another important application of L-glutaminase is in biosensors for monitoring glutamine levels in mammalian and hybridoma cell cultures without the need of separate measurement of glutamic acid[11]. Marine microorganisms hold significance in food industry by virtue of their ability to produce salt tolerant Lglutaminase, as salt and thermo tolerant glutaminases are needed in soy sauce fermentation[12]. Renu and Chandrasekhar[11] isolated extra cellular L-glutaminaseproducing bacteria from seawater and marine sediments from environments at Cochin and observed that their populations were on the order of 105 cells/per ml or gm. Species of Pseudomonas, Vibrio, Bacillus,

\section{How to cite this article:}

S. Suneetha et. al., Screening and isolation of I-glutaminase producing marine bacterial cultures. Int. J. Adv. Pharm. Biotech., 2015; 1(1): 28-32. 
Moraxella, Aeromonas,and Acinetobacter producing L-glutaminase were also recovered[11, 13]. Different methods of fermentation technology can be applied for the production of L-Glutaminase.Commercial production of L- Glutaminase is carried out using SmF (Submerged fermentation) technique. Since the present source for this enzyme is limited to marine bacteria alone, importance is given to SmF (Submerged fermentation) technique only.

\section{MATERIALS AND METHODS}

\section{Screening Procedure}

Soil and water samples were collected from different places along the beach of Bay of Bengal in Visakhapatnam. All the samples were collected in sterile screw capped tubes and care was taken to see that the points of collection had as widely varying characteristics as possible as regard to the organic matter, moisture content, particle size, colour of soil and geographical distribution.

About $1 \mathrm{~g}$ of each of above samples were taken into $50 \mathrm{ml}$ of sterile water. The suspension was kept on rotary shaker for 30 min and kept aside to settle the soil matter. One $\mathrm{ml}$ of the suspension was serially diluted five times with sterile water and $0.5 \mathrm{ml}$ of each of these dilutions was added to $50 \mathrm{ml}$ of sterile isolation medium (Yeast Extract $0.5 \mathrm{~g}$, Peptone 0.5 g, Agar 20 g, and Aged Sea Water $1000 \mathrm{ml}$ )

This media, after sufficient mixing were plated in 6-inch dia sterile petridishes and incubated at $37^{\circ} \mathrm{C}$. Similarly, water samples were also diluted five times individually and plated as above. (Cyclohexamine $50 \mu \mathrm{g} / \mathrm{ml}$ is used as antifungal agent). Total thirty individual bacterial colonies have different macroscopic characters were selected from the plates after $40 \mathrm{~h}$ of incubation at $37^{\circ} \mathrm{C}$. After preliminary screening, thirty five bacterial strains were selected to study enzymatic activity depending on the colony size, texture and macroscopic characteristics. After isolation the bacterial strains were maintained on the Nutrient agar slants.

\section{Detection of L-glutaminase positive cultures}

Minimal agar medium (KCl 0.5 g, $\mathrm{MgSO}_{4} .7 \mathrm{H}_{2} \mathrm{O}$ $0.5 \mathrm{~g}, \mathrm{FeSO}_{4} .7 \mathrm{H}_{2} \mathrm{O} 0.1 \mathrm{~g}, \mathrm{ZnSO}_{4} .7 \mathrm{H}_{2} \mathrm{O} 1.0 \mathrm{~g}$, $\mathrm{KH}_{2} \mathrm{PO}_{4} 1.0$ g, L-Glutamine $0.5 \%$, Phenol red $0.012 \mathrm{~g}$, Aged Sea Water $1000 \mathrm{ml}$ ) contains $0.5 \%$ L-glutamine as the sole carbon and nitrogen source and phenol red as $\mathrm{pH}$ indicator. The colour change of the medium from yellow to pink is an indication of the extra cellular L- glutaminase production by the colony. This colour change is due to change in the $\mathrm{pH}$ of the medium, as Lglutaminase causes the breakdown of amide bond in L- glutamine and librates ammonia. All the bacterial strains collected were streaked in small Petri plates with minimal agar medium individually. After two days of incubation at $37^{\circ} \mathrm{C}$ the plates turned pink indicating positive response. Out of 30 bacterial strains, 15 are positive out of which 5 from sediment, 5 from water collected in tenneti park area and 5 from water collected in sagar nagar area. These strains were used for further study.

\section{Inoculum preparation}

Sterile sea water $5 \mathrm{ml}$ was aseptically added to $48 \mathrm{~h}$ old Nutrient agar culture slants and cell suspension was prepared. This suspension was added to $45 \mathrm{ml}$ of inoculum medium (Peptone $5 \mathrm{~g}$, Yeast extract $1 \mathrm{~g}$, Nacl $2.45 \mathrm{~g}$, Aged Sea water $1000 \mathrm{ml}$ ). The inoculated medium was kept on a rotary shaker at $200 \mathrm{rpm}$ for $48 \mathrm{~h}$. Then $10 \%$ inoculation medium is used as inoculum.

\section{Production}

From the prepared inoculum $5 \mathrm{ml}$ was transferred aseptically to $45 \mathrm{ml}$ of production medium (SWG) Sea water glutamine medium: L-Glutamine $20 \mathrm{~g}$, D-Glucose $10 \mathrm{~g}$, Aged Sea water $1000 \mathrm{ml}, \mathrm{pH}$ 8. The flasks were kept on an orbital shaking incubator at $35^{\circ} \mathrm{C}$ and at $120 \mathrm{rpm}$ for $48 \mathrm{~h}$. The samples withdrawn were centrifuged at $1500 \mathrm{rpm}$ for $30 \mathrm{~min}$ and the clear supernatant was used for enzyme estimation.

\section{Glutaminase activity}

The activity of glutaminase is determined by estimating the amount of $\mathrm{NH}_{3}$ liberated from glutaminase. The activity of an enzyme was 
determined by following Imada et. al.[17] method using ammonium sulfate as the standard. Enzyme preparation of about $0.5 \mathrm{ml}$ was added to $0.5 \mathrm{ml}$ of $0.04 \mathrm{M} \mathrm{L}$-glutamine and $0.5 \mathrm{ml}$ of distilled water. To this $0.5 \mathrm{ml}$ of $0.5 \mathrm{M}$ tris buffer $(\mathrm{pH}-8)$ was added and incubated at $37^{\circ} \mathrm{C}$ for $15 \mathrm{~min}$. After incubation $0.5 \mathrm{ml}$ of $1.5 \mathrm{M}$ trichloroacetic acid was added to stop the enzyme reaction. Blank tubes were run by adding the enzyme preparation after the addition of trichloroacetic acid. Then $0.1 \mathrm{ml}$ of above mixture was taken and added to $3.7 \mathrm{ml}$ of distilled water. Then $0.2 \mathrm{ml}$ Nessler's reagent was added to it. Absorbance was measured at $450 \mathrm{~nm}$ using a visible spectrophotometer.

Standard graph was prepared by treating 1 $\mathrm{ml}$ of various concentrations $(0.5 \mathrm{mM}, 1 \mathrm{mM}$, $1.5 \mathrm{mM}, 2 \mathrm{mM}, 2.5 \mathrm{mM}$ etc.) of ammonium sulphate with $0.5 \mathrm{ml}$ of $0.5 \mathrm{M}$ tris buffer, 0.5 $\mathrm{ml}$ of 1.5M TCA, and Nessler's reagent. One international unit of glutaminase was defined as amount of enzyme that liberates one micromole of ammonia under optimum conditions. The enzyme yield was expressed as units $/ \mathrm{ml}(\mathrm{U} / \mathrm{ml})$.

\section{RESULTS AND DISCUSSION}

The selected 15 isolates were used for glutaminase production in medium containing L- glutamine, D-glucose dissolved in sea water and $\mathrm{pH}$ adjusted to 8 at $35^{\circ} \mathrm{C}$ and at $120 \mathrm{rpm}$. The samples were withdrawn for every $24 \mathrm{~h}$ up to $120 \mathrm{~h}$ and assayed for glutaminase activity. The isolate $\mathrm{LG}_{24}$ exhibited maximum glutaminase activity of $18.82 \mathrm{U} / \mathrm{ml}$ among all 15 isolates. The results showing the yields of all 15 isolated strains were given in table 1 .

The present work was carried out to identify L-glutaminase producing cultures isolated from marine samples. A semi quantitative plate assay is used for screening of Lglutaminase producing microorganisms. The plate assay was devised using this principle by incorporating the $\mathrm{pH}$ indicator phenol red in the medium containing glutamine (sole carbon and nitrogen sources). Phenol red at acidic $\mathrm{pH}$ is yellow and at alkaline $\mathrm{pH}$ turns pink, thus a pink zone is formed around the microbial colonies producing L-glutaminase.
Table 1: Glutaminase production by the selected isolates

\begin{tabular}{|c|c|}
\hline Isolate number & Yield (U/ml) \\
\hline $\mathrm{LG}_{1}$ & 11.76 \\
\hline $\mathrm{LG}_{3}$ & 9.41 \\
\hline $\mathrm{LG}_{4}$ & 3.53 \\
\hline $\mathrm{LG}_{12}$ & 4.71 \\
\hline $\mathrm{LG}_{13}$ & 7.53 \\
\hline $\mathrm{LG}_{14}$ & 10.59 \\
\hline $\mathrm{LG}_{17}$ & 7.29 \\
\hline $\mathrm{LG}_{18}$ & 5.88 \\
\hline $\mathrm{LG}_{23}$ & 7.29 \\
\hline $\mathbf{L G}_{24}$ & 18.82 \\
\hline $\mathrm{LG}_{25}$ & 10.94 \\
\hline $\mathrm{LG}_{26}$ & 7.86 \\
\hline $\mathrm{LG}_{27}$ & 5.04 \\
\hline $\mathrm{LG}_{28}$ & 4.24 \\
\hline $\mathrm{LG}_{30}$ & 5.27 \\
\hline
\end{tabular}

The plate assay used for screening the isolates to determine their glutaminase activity (equal to diameter of the pink zone) is also an indication of the amount of glutaminase produced by the colony or isolate (fig. 1). The different isolates exhibited pink zones around them. The size or diameter of these zones was proportional to the glutaminase produced by the colony. This revealed that isolated $\mathrm{LG}_{24}$ had the maximum glutaminase activity. However all the 15 isolates were employed for glutaminase production by submerged fermentation and the results were reported in Table 1.

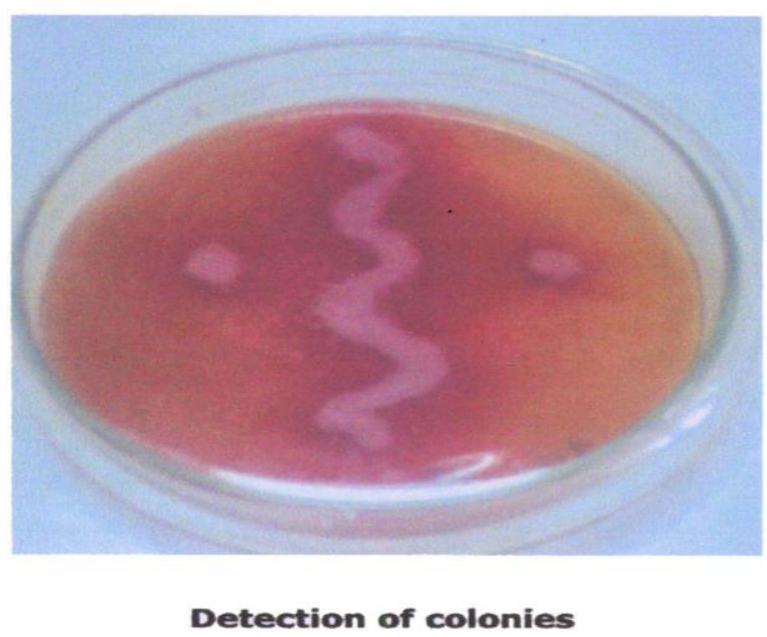

Fig. 1: Glutaminase positive colony on agar medium 
As expected isolate $\mathrm{LG}_{24}$ which exhibited a pink zone with maximum diameter also produced the maximum amount of glutaminase in submerged fermentation.

\section{CONCLUSION}

The results of the preliminary study indicates that L-glutaminase positive marine bacterial strain $\mathrm{LG}_{24}$ could be a source for extracellular L-glutaminase production with possible utilization as potential source for antileukemic agent and flavor enhancing agent in the food industries after the extensive therapeutic activity determination. As it is of marine isolate it could tolerate the high salt concentrations in food industries which may affect the enzyme activity. Extensive bioprocess parameter studies should underway for microbial production of Lglutaminase for the isolated strain.

\section{REFERENCES}

[1] Roberts J, Holchenberg JS, Dollowy WC. Antineoplastic activity of highly purified bacterial glutaminases. Nature, 1970; 227(263): 1136-7.

[2] Schmid FA, Roberts J. Antineoplastic and toxic effects of Acinetobacter and Pseudomonas glutaminase asparaginases. Cancer Chemother Rep., 1974; 58(6): 829-40.

[3] Robert J, MacAllister TW, Sethuraman N, Freeman AG. Genetically engineered glutaminase and its use in antiviral and anticancer therapy. US Patent, 6312939, November 6, 2001.

[4] Lund P.L-Glutamine and L-glutamate.UV method with glutaminase and glutamate dehydrogenase. In: Bergmeyer HU, editor. Methods of enzymatic analysis, vol. 8. Weinhem: VCH, Verlagssgesellschaft, 1986; 357-363.

[5] Villarta RL, Palleschi G, Suleiman A, Guilbault GG. Determination of glutamine in serum using an amperometric enzyme electrode. Electro analysis, 1992; 4(1): 27-31.

[6] Mulchandani A, Bassi AS. Determination of glutamine and glutamic acid in mammalian cell cultures using tetrathiafulvaline modified enzyme electrodes. Biosensor Bioelectron, 1996; 11(3): 271- 80.

[7] Tachiki T, Yamada T, Mizuno K, Ueda M, Shide J, Fukami H. Gamma glutamyl transfer reactions by glutaminase from Pseudomonas nitroreducens IFO 12694 and their application for the synthesis of threonine and gamma glutamyl methylamide. Biosci Biotechnol Biochem., 1998; 62(7): 1279-83.

[8] Roberts J, Holcenberg JS .and Dolowy WC, Antineoplastic activity of highly purification bacterial glutaminases. Nature, 1970; 227: 1136-1137.

[9] Yokatsuke T, Fermented protein foods in the Orient, with emphasis on shoy and miso in Japan. In: Wood BJB. Editor.

Microbiology of Fermented foods. London, Elsevier Applied Science, 1985; 197-247.

[10] Prabhu GN and Chandrasekaran M, Impact of process parameters on Lglutaminase production by marine Vibrio costicola under solid state fermentation using polystyrene as inert support, Process Biochem., 1997; 32(4): 285-289.

[11]Sabu A, Keerthi TR, Rajeev Kumar S. and Chandrasekharan M, L- Glutaminase production by marine Beauveria sp. Under solid state fermentation. Process Biochem., 2000; 35: 705.

[12] Chandrasekaran M,Industrial enzymes from marine microorganisms: The Indian scenario. J. Mar Biotechnology, 1997; 5: 86-89. [13] Renu S and Chandrasekharan $M$, Extracellular L-glutaminase by marine bacteria. Biotechnology letters, 1992; 14; 471474.

[14] Prabhu GN and Chandrasekaran M, Lglutaminase production by marineVibrio costicola under solid state fermentation using different substrates. J.Mar. Biotechnol. 1996; 4: 176-9.

[15] Prabhu GN and Chandrasekaran M, Polystyrene an inert carrier for L-glutaminase production by marine Vibrio costicola under solid state fermentation. World J. Microbiol Biotechnol., 1995; 11: 683-4.

[16] Moriguchi M, Sakai K, Tateyama R, Furuta $\mathrm{Y}$ and Wakayama $\mathrm{M}$, Isolation and characterization of salt-tolerant glutaminases from marine Micrococcus luteusK-3, J. Ferment Bioengy., 1994; 77: 621-625.

[17] Dharmaraj K, Selvakumar N, Chandramohan D and Natarajan R, Lglutaminase activity in marine sediments. Indian J. Mar.Sci., 1977; 6: 168.

[18] Imada A, Igarasi S, Nakahama K and Isono $\mathrm{M}$, Asparaginase and glutaminase activity of micro-organisms. J.Gen. Microbiol., 
1973; 76: 85. investigated by in-vitro method. The sustained activity was due to the controlled release of drug into the systemic circulation following transdermal administration. 